\title{
PRINSIP BIOLOGI DALAM LINGKUNGAN BERKELANJUTAN
}

\author{
Misbakhul Munir \\ ${ }^{1}$ Fakultas Sains dan Teknologi, Universitas Islam Negeri Sunan Ampel, Jl. Jend. A. Yani 117 Surabaya \\ Email :misbakhul_munir@uinsby.ac.id
}

\begin{abstract}
ABSTRAK
Masalah lingkungan bagi para ahli biologi sudah sejak lama menjadi perhatian. Hal ini tidaklah mengejutkan karena ekologi yang kajiannya tentang interaksi antara organisme dengan lingkungan merupakan salah satu cabang biologi yang penting. Masalah lingkungan yang sekarang dihadapi oleh seluruh bangsa adalah masalah yang berkaitan dengan kepentingan hidup manusia yang pada hakekatnya adalah masalah ekologi dan lebih khusus lagi masalah ekologi manusia. Suatu masalah dapat diartikan sebagai sesuatu yang menghalangi atau merintangi keinginan dan harapan manusia. Masalah dipersepsikan sebagai kesenjangan diantara realita dan harapan harapan kita yang semestinya. Dengan demikian masalah lingkungan adalah kondisi-kondisi lingkungan biofisik yang merintangi kepuasan dan kebutuhan manusia untuk kesehatan dan kebahagiaan (Swan \& Stapp, 1974). Prinsip-prinsip biologi tentang lingkungan berkelanjutan (sustainability) memberikan suatu kerangka kerja untuk perubahan ekonomi, politik dan perubahan personal (Chiras, 1993). Bila prinsip berkelanjutan diterapkan terhadap kegiatan manusia, maka pemecahan masalah lingkungan tidak hanya ditujukan pada akar penyebabnya krisis tetapi juga membantu menciptakan pemecahan yang sistemik yang dapat menanggulangi berbagai masalah lingkungan. Pemecahan pada tingkat akar permasalahan merupakan penerapan prinsip berkelanjutan yang ditujukan terhadap beberapa masalah lingkungan secara simultan. Di samping itu juga bahwa pemecahan pada tingkat akar permasalahan dapat mengurangi tenaga dan uang dibanding dengan pemecahan secara tradisional. Peran aktif di dalam transformasi prinsip berkelanjutan, melalui berbagai cara, diantaranya: mempengaruhi perilaku orang lain di sekeliling kita, mendorong perubahan kebijakan publik melalui surat, lobby, kerjasama dan usaha lainnya, menjadi warga negara yang lebih baik dengan berpikir dan bertindak berdasarkan prinsip lingkungan berkelanjutan.
\end{abstract}

Kata kunci: biologi, lingkungan, berkelanjutan

\section{PENDAHULUAN}

Masalah lingkungan bagi para ahli biologi sudah sejak lama menjadi perhatian. Hal ini tidaklah mengejutkan karena ekologi yang kajiannya tentang interaksi antara organisme dengan lingkungan merupakan salah satu cabang biologi yang penting. Masalah lingkungan yang sekarang dihadapi oleh seluruh bangsa adalah masalah yang berkaitan dengan kepentingan hidup manusia yang pada hakekatnya adalah masalah ekologi dan lebih khusus lagi masalah ekologi manusia. Suatu masalah dapat diartikan sebagai sesuatu yang menghalangi atau merintangi keinginan dan harapan manusia. Masalah dipersepsikan sebagai kesenjangan diantara realita dan harapan harapan kita yang semestinya. Dengan demikian masalah lingkungan adalah kondisi-kondisi lingkungan biofisik yang merintangi kepuasan dan kebutuhan manusia untuk kesehatan dan kebahagiaan (Swan \& Stapp, 1974).

Berkaitan dengan kebutuhan manusia ada satu teori yang dikemukakan Maslow (1970) yang disebut Grumbles Theory (Teori Keluhan) atau Maslow's Hierarchy yang diawali dengan kebutuhan paling dasar, yaitu kebutuhan fisiologis seperti makanan dan air sampai kepada kebutuhan fisiologis seperti keselamatan, rasa dicintai dan mencintai, rasa memiliki sampai kepada aktualisasi diri. Bila kebutuhan-kebutuhan tersebut tak dapat dipenuhi karena sesuatu hal maka manusia akan mengeluh dan hal tersebut merupakan masalah. Dalam kaitannya dengan lingkungan maka lingkungan yang menjadi rintangan atau penghalang untuk memenuhi kebutuhan tersebut.

Masalah-masalah tersebut dapat timbul karena ada perubahan di dalam lingkungan sehingga lingkungan tersebut tidak sesuai lagi dan tidak mendukung kehidupan manusia serta mengganggu kesejahteraan hidupnya (Soemarwoto, 1992). Lingkungan yang dimaksudkan adalah lingkungan hidup, yaitu : segala benda, kondisi dan pengaruh yang terdapat dalam ruang yang kita tempati dan mempengaruhi segala hal yang hidup termasuk manusia. Dengan demikian maka masalah lingkungan tersebut bersumber pada ketidakseimbangan dalam lingkungan hidup manusia (Salim, 1982).

Masalah lingkungan bukan lagi menjadi masalah suatu bangsa dan negara saja tetapi seluruh dunia dihadapkan pada masalah yang sangat kompleks dan pelik. Kita bahkan semua lapisan masyarakat sudah tahu tentang masalah tersebut sehingga tak perlu dirinci satu persatu. Kompleksnya dan menyeluruhnya masalah lingkungan dapat dibuktikan dengan tayangan di berbagai media cetak dan media elektronik yang hampir tiap hari dimunculkan. Dari sekian 
banyak permasalahan yang dihadapi mulai dari masalah pangan, energi, kerusakan lingkungan, industrialisasi, pencemaran, pengangguran perekonomian sampai masalah sosial sepintas tampaknya terpisah-pisah tetapi kalau dicermati akan tampak bahwa permasalahan tersebut saling kait mengait dan bersumber pada rangkaian masalah pokok, yaitu: dinamika kependudukan, pengembangan sumber daya alam dan energi, pertumbuhan ekonomi dan perkembangan ilmu dan teknologi serta benturan terhadap tata lingkungan (Zen, 1979).

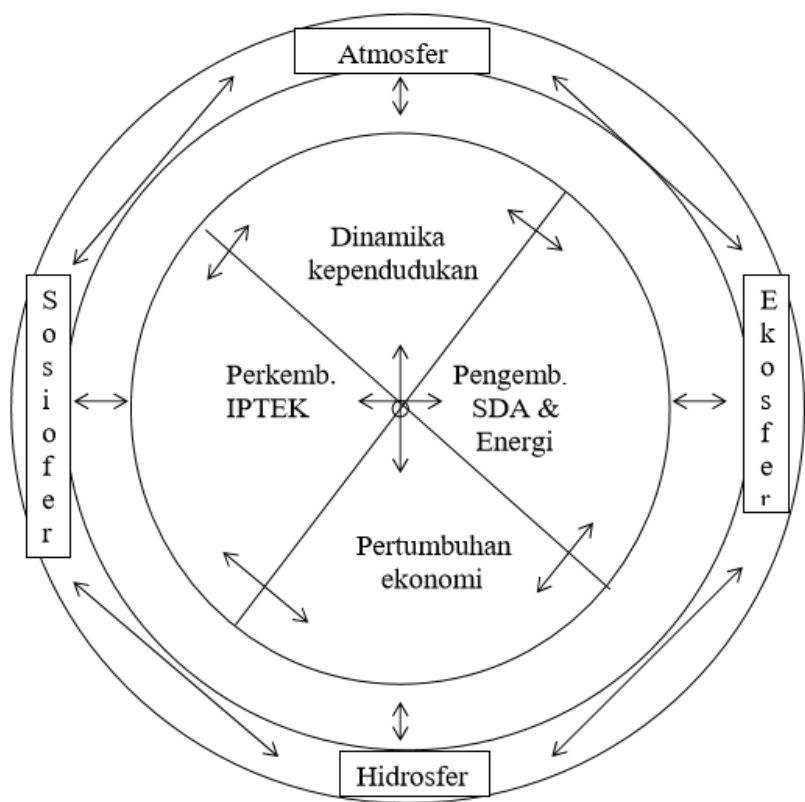

Gambar 1. Interaksi antara dinamika kependudukan, pengembangan SDA dan energi, pertumbuhan ekonomi, perkembangan IPTEK serta benturan terhadap tata lingkungan.

Untuk dapat memulihkan keseimbangan lingkungan yang rusak adalah penting untuk menciptakan keragaman dalam sistem lingkungan. Semakin beragam isi lingkungan maka makin stabil sistem tersebut. Beragamnya isi lingkungan akan memperbesar daya dukung lingkungan untuk menampung gangguan-gangguan. Pembangunan pada hakekatnya menimbulkan keragaman dan diversifikasi dalam kegiatan ekonomi (Salim, 1981).

Semakin beragam kegiatan ekonomi semakin besar kemampuan ekonomi negara itu untuk tumbuh cepat dan stabil. Namun demikian, keragaman dalam kegiatan ekonomi harus sejalan dengan usaha meragamkan sistem lingkungan. Hal ini hanya mungkin apabila dalam proses pembangunan sudah diperhitungkan segi lingkungan hidup dan diusahakan keselarasan antara pengembangan keragaman kegiatan ekonomi dengan pengembangan keragaman sistem lingkungan.

Ada dua hal yang paling menggoncangkan keseimbangan lingkungan, yaitu perkembangan ilmu dan teknologi serta ledakan penduduk (Salim, 1981). Perkembangan IPTEK telah mengubah keadaan lingkungan tempat hidup sehingga menimbulkan gangguan. Ledakan penduduk yang terjadi telah memicu percepatan perubahan lingkungan agar kebutuhan manusia dapat terpenuhi. Ledakan penduduk telah mendorong keharusan untuk melancarkan pembangunan sekaligus dengan pengembangan lingkungan.

\section{HASIL DAN PEMBAHASAN}

\section{Makna Pembangunan Berkelanjutan}

Pembangunan adalah sebuah proses produksi dan konsumsi dimana materi dan energi diolah dengan menggunakan faktor produksi, seperti modal, mesin mesin (capital), tenaga kerja (labor and human resources), dan bahan baku (natural resources). Dalam hal penyediaan bahan baku dan proses produksi kegiatan pembangunan dapat membawa dampak kepada lingkungan alam dan masyarakat sekitarnya, yang pada gilirannya akan berdampak kepada keberlanjutan pembangunan. Dalam memperhatikan keberlanjutan pembangunan yang tidak hanya memperhatikan 
kepentingan saat ini tapi juga memperhatikan kepentingan masa mendatang, maka pembangunan harus dilaksanakan secara berkelanjutan.

Pembangunan berkelanjutan adalah pembangunan yang memenuhi kebutuhan masa kini tanpa mengurangi kemampuan generasi masa mendatang. Didalamnya terdapat dua gagasan penting Tujuan yang harus dicapai untuk keberlanjutan pembangunan adalah : keberlanjutan ekologis, keberlanjutan ekonomi, keberlajutan sosial budaya dan politik, keberlanjutan pertahanan dan keamanan. Sedangkan pembangunan keberlanjutan mempunyai prinsip prinsip dasar dan prinsip dasar tersebut dari setiap elemen pembangunan berkelanjutan dapat diringkas menjadi 4 (empat), yaitu: pemerataan, partisipasi, keanekaragaman (diversity), integrasi dan perspektif jangka panjang.

Pembangunan berkelanjutan memastikan bahwa generasi yang akan datang memiliki kesempatan ekonomi yang sama dalam mencapai kesejahteraannya, sepertihalnya generasi sekarang. Untuk dapat melaksanakan pembangunan berkelanjutan diperlukan cara mengelola dan memperbaiki portofolio asset ekonomi, sehingga nilai agregatnya tidak berkurang dengan berjalannya waktu. Portofolio asset ekonomi tersebut adalah capital alami (Kn), capital fisik (Kp) dan capital manusia (Kh). Dalam paradigma ekonomi, pembangunan berkelanjutan dapat diterjemahkan sebagai pemeliharaan kapital. Ada empat variasi kebijakan mengenai pembangunan berkelanjutan :

a. Kesinambungan yang sangat lemah (very weak sustainabillity) atau "Hartwick-Solow sustainability" yang hanya mensyaratkan kapital dasar total yang harus dipelihara. Kesinambungan ini dapat dicapai dengan memastikan bahwa tingkat/ laju konsumsi berada di bawah Hicksian income, dimana Hicksian income ini didefinisikan sebagai tingkat konsumsi maksimum yang dapat membangun kondisi masyarakat yang lebih sejahtera di akhir periode pembangunan dibandingkan dengan kondisi awalnya. Diasumsikan natural capital dapat disubsitusi dengan kapital buatan manusia (man-made capital) tanpa batas. Dengan kata lain, deplesi sumberdaya alam tidak diperhitungkan dalam penilaian kegiatan ekonomi (Harnett, 1998).

b. Kesinambungan yang lemah (weak sustainability), mensyaratkan pemeliharaan kapital total, dengan kendala bahwa modal alami yang penting (critical natural capital) harus dilestarikan. Misalnya : bila sumberdaya air dan keragaman spesies merupakan hal yang penting bagi stabilitas ekosistem, sumberdaya tersebut tidak dapat dikorbankan bagi alasan-alasan pertumbuhan ekonomi.

c. Kesinambungan yang kuat (strong sustainability) mensyaratkan bahwa tidak ada substitusi bagi modal alami (natural capital), karena natural capital ini memperkuat kesejahteraan manusia dan degradasi natural capital tersebut dapat dikembalikan kondisinya ke kondisi awal. Kesinambungan yang kuat mensyaratkan pemeliharaan kapital total, dengan kendala bahwa agregrat kapital total harus dilestarikan.

d. Kesinambungan yang sangat kuat (very strong sustainability) mensyaratkan bahwa kesinambungan sistem ekologi adalah esensi pembangunan ekonomi yang berkelanjutan. Pembangunan yang bergantung pada sumberdaya (resource-dependent "development") diperbolehkan, namun demikian, pertumbuhan yang bergantung pada sumberdaya (resources-dependent "growth") tidak dapat dibenarkan. Interpretasi ini mensyaratkan pemisahan setiap komponen dari natural capital. Pada kenyataannya, very strong sustainability lebih merupakan sistem daripada suatu konsep ekonomi.

Pada pembangunan berkelanjutan yang berorientasi pada kepentingan ekonomi dan kepentingan lingkungan, terdapat 3 (tiga) pilar tujuan (Daniel M, 2003), yaitu :

1. Pilar 1, pembangunan ekonomi yang berorientasi pada pertumbuhan, stabilitas dan efisiensi.

2. Pada pilar 2, pembangunan sosial yang bertujuan pengentasan kemiskinan, pengakuan jati diri dan pemberdayaan masyarakat.

3. Sedangkan pilar 3, pembangunan lingkungan yang berorientasi pada perbaikan lingkungan lokal seperti sanitasi lingkungan, industri yang lebih bersih dan rendah emisi, dan kelestarian sumberdaya alam.

Tahun 1992 merupakan puncak dari proses politik, yang akhirnya pada konferensi tingkat tinggi (KTT) Bumi di Rio de Jainero, Brazil, paradigma Pembangunan Berkelanjutan diterima sebagai sebuah agenda politik pembangunan untuk semua negara di dunia (Keraf, 2001). Selain itu ada pula beberapa pakar yang memberikan rumusan untuk lebih menjelaskan makna dari pembangunan yang berkelanjutan itu antara lain:

\section{Emil Salim}

Yang dimaksud dengan pembangunan berkelanjutan adalah suatu proses pembangunan yang mengoptimalkan manfaat dari sumber daya alam dan sumberdaya manusia, dengan menyerasikan sumberdaya alam dengan manusia dalam pembangunan. 


\section{Ignas Kleden}

Pembangunan berkelanjutan di sini untuk sementara didefinisikan sebagai jenis pembangunan yang di satu pihak mengacu pada pemanfaatan sumber-sumber alam maupun sumber daya manusia secara optimal, dan di lain pihak serta pada saat yang sama memelihara keseimbangan optimal di antara berbagai tuntutan yang saling bertentangan terhadap sumberdaya tersebut.

\section{Sofyan Effendi}

a. Pembangunan berkelanjutan adalah suatu proses pembangunan yang pengembangan teknologinya dan perubahan kelembagaannya dilakukan secara harmonis dan dengan amat memperhatikan potensi pada saat ini dan masa depan dalam pemenuhan kebutuhan dan aspirasi masyarakat.

b. Secara konseptual, pembangunan berkelanjutan dapat diartikan sebagai transformasi progresif terhadap struktur sosial, ekonomi dan politik untuk meningkatkan kepastian masyarakat Indonesia dalam memenuhi kepentingannya pada saat ini tanpa mengorbankan kemampuan generasi mendatang untuk memenuhi kepentingan mereka. Konsep keberlanjutan ini paling tidak mengandung dua dimensi, yaitu dimensi waktu karena keberlanjutan tidak lain menyangkut apa yang akan terjadi di masa mendatang, dan dimensi interaksi antara system ekonomi dan sistem sumberdaya alam dan lingkungan.

Dalam kaitannya dengan pembangunan berkelanjutan, terdapat dua kaidah yang harus diperhatikan dalam pengelolaan sumberdaya alam dan lingkungan, yaitu:

1. Untuk sumberdaya alam yang terbarukan (renewable resources): Laju pemanenan harus lebih kecil atau sama dengan laju regenerasi (produksi lestari).

2. Untuk masalah lingkungan: Laju pembuangan (limbah) harus lebih kecil atau setara dengan kapasitas asimilasi lingkungan.

Aspek operasional dari konsep keberlanjutan ini dapat dipahami lebih jauh dengan adanya lima alternatif pengertian sebagaimana yang diuraikan sebagai berikut:

1. Suatu kondisi dikatakan berkelanjutan (sustainable) jika utilitas yang diperoleh masyarakat tidak berkurang sepanjang waktu dan konsumsi tidak menurun sepanjang waktu (non-declining consumption).

2. Keberlanjutan adalah kondisi dimana sumberdaya alam dikelola sedemikian rupa untuk memelihara kesempatan produksi di masa mendatang.

3. Keberlanjutan adalah kondisi dimana sumberdaya alam (natural capital stock) tidak berkurang sepanjang waktu (non-declining).

4. Keberlanjutan adalah kondisi dimana sumberdaya alam dikelola untuk mempertahankan produksi jasa sumberdaya alam.

5. Keberlanjutan adalah kondisi dimana kondisi minimum keseimbangan dan daya tahan (resilience) ekosistem terpenuhi.

Selain definisi operasional diatas, melihat bahwa konsep keberlanjutan dapat diperinci menjadi tiga aspek pemahaman, yaitu:

1. Keberlanjutan ekonomi, yang diartikan sebagai pembangunan yang mampu menghasilkan barang dan jasa secara kontinu untuk memelihara keberlanjutan pemerintahan dan menghindari terjadinya ketidakseimbangan sektoral yang dapat merusak produksi pertanian dan industri.

2. Keberlanjutan lingkungan: Sistem yang berkelanjutan secara lingkungan harus mampu memelihara sumberdaya yang stabil, menghindari eksploitasi sumberdaya alam dan fungsi penyerapan lingkungan. Konsep ini juga menyangkut pemeliharaan keanekaragaman hayati, stabilitas ruang udara, dan fungsi ekosistem lainnya yang tidak termasuk kategori sumber-sumber ekonomi.

3. Keberlanjutan sosial: Keberlanjutan secara sosial diartikan sebagai sistem yang mampu mencapai kesetaraan, menyediakan layanan sosial termasuk kesehatan, pendidikan, gender, dan akuntabilitas politik

Konsep pembangunan berkelanjutan berhubungan erat dengan masalah etika, mengingat bahwa konsep pembangunan berkelanjutan berorientasi pada masa depan (future) dan juga memfokuskan diri pada masalah kemiskinan (poverty). Konsep ini sangat memperhatikan kesejahteraan generasi yang akan datang, namun pada saat yang bersamaan juga tidak mengurangi perhatian terhadap upaya-upaya untuk meningkatkan taraf hidup orang-orang miskin yang ada pada generasi sekarang. Tujuan pembangunan berkelanjutan yang bermutu adalah tercapainya standar kesejahteraan hidup manusia dunia akhirat yang layak, cukup sandang, pangan, papan, pendidikan bagi anak-anaknya, kesehatan yang 
baik, lapangan kerja yang diperlukan, keamanan dan kebebasan berpolitik, kebebasan dari ketakutan dan tindak kekerasan, dan kebebasan untuk menggunakan hak-haknya sebagai warga Negara.

Pembangunan berkelanjutan dapat diartikan pula perubahan positif sosial ekonomi yang tidak mengabaikan sistem ekologi dan sosial di mana masyarakat bergantung kepadanya. Keberhasilan penerapannya memerlukan kebijakan, perencanaan dan proses pembelajaran sosial yang terpadu, viabilitas politiknya bergantung pada dukungan penuh masyarakat melalui pemerintah, kelembagaan sosial dan kegiatan dunia usaha (Sumarwoto, 2006).

Pembangunan berkelanjutan sesungguhnya merupakan wacana moral dan kultural. Hal ini disebabkan karena yang menjadi persoalan utama adalah pada bentuk dan arah peradaban seperti apa yang akan dikembangkan manusia di Bumi ini. Kearifan lingkungan lokal, sekaligus plural perlu terus dikembangkan. Tetapi tidak hanya diposisikan sebagai upaya untuk "melawan" kecenderungan globalisasi dan westernisasi, melainkan satu "pilihan". Dengan kata lain, pengembangan kearifan lingkungan tidak selalu harus "dibenturkan" globalisasi/westernisasi, karena dia adalah "keyakinan" sekaligus "pilihan-pilihan" sadar tiap kelompok manusia di Bumi untuk mengembangkan peradaban yang plural, sekaligus identitas yang beragam.

Dalam proses pelaksanaan pembangunan atau kegiatan ekonomi, komponen-komponen lingkungan tersebut kemungkinan akan mengalami perubahan atau lebih dikenal terkena dampak dari suatu kegiatan pembangunan. Perubahan lingkungan tersebut dapat bersifat global, nasional maupun lokal. Ketiganya harus dilihat secara menyeluruh danterpadu oleh karena memang ketiganya tidaklah dapat dipisahkan dansaling terkait. Lebih lanjut, perlu dipahami bahwa keterkaitan antara permasalahan lingkungan global dan lokal sangatlah erat. Sebagai contoh, membicarakan Agenda 21 Indonesia tidak dapat dilepaskan dari Agenda 21 Rio karena yang terakhir inilah yang mendasari terciptanya Agenda 21 Indonesia. Demikian juga, dalam membicarakan isu lingkungan global perlu juga diimbangi dengan pembicaraan tentang isu lingkungan nasional (Indonesia) untuk melihat keterkaitan permasalahan lingkungan Indonesia dengan permasalahan global.

Konsep pembangunan berkelanjutan memberikan himbauan bahwa pembangunan akan memungkinkan generasi sekarang meningkatkan kesejahteraan, tanpa mengurangi hak generasi masa depan juga meningkat kesejahteraannya. Terdapat tiga pilar pembangunan berkelanjutanyang ditekankan perlunya koordinasi dan integrasi yakni aspek sosial, ekonomi dan lingkungan. Pembangunan berkelanjutan memerlukan keterpaduaan koordinasi yang mantap antara pemanfaatan sumber daya alam, sumberdaya manusia, dan sumberdaya buatan dalamsuatu kurun waktu, dimensi ruang agar tepat guna, berhasil guna dan berdayaguna.

\section{Prinsip Lingkungan Berkelanjutan}

Prinsip berkelanjutan (sustainability) memiliki implikasi kemampuan untuk bertahan. Dalam ekologi artinya cukup sederhana yaitu hidup di dalam daya dukung biosfer. Daya dukung dimaksudkan sebagai kemampuan untuk mengasimilasi sampah, menyediakan makanan dan sumber lainnya dalam waktu yang lama (Chiras, 1992). Untuk para ilmuwan, krisis tidak berkelanjutan (unsustainability) disebabkan kehidupan kita melebihi daya dukung bumi. Oleh karena itu agar krisis tersebut dapat diatasi perlu membawa masyarakat agar hidupnya sejalan dengan prinsipprinsip ekologi yang mampu menciptakan hubungan yang berkelanjutan dengan planet bumi (Chiras, 1991).

Masyarakat yang berkelanjutan (sustainable society) hidup di dalam lingkungan dengan daya dukung dan mencari sumber-sumber lain yang cukup untuk generasi yang banyak. Pada masyarakat yang seperti ini, bumi dipandang sebagai pusaka yang tidak ternilai yang harus diwariskan dari satu generasi ke generasi berikutnya. Hasil studi Chiras (1993) tentang ekosistem alamiah (yang tidak tersentuh oleh tindakan manusia) berkesimpulan bahwa ekosistem alamiah dapat tetap bertahan karena spesies yang hidup di dalam ekosistem tersebut "mengikuti" lima aturan ekologi, yaitu:
a. konservasi (effisiensi),
b. daur ulang (recycling),
c. penggunaan sumber yang dapat diperbaharui (renewable resource use),
d. pengendalian populasi (population control) dan prinsip regenerasi,
e. restorasi (self healing).

\section{Prinsip Biologi Mengenai Lingkungan Berkelanjutan}

Prinsip-prinsip biologi tentang lingkungan berkelanjutan (sustainability) memberikan suatu kerangka kerja untuk perubahan ekonomi, politik dan perubahan personal (Chiras, 1993). Bila prinsip berkelanjutan diterapkan terhadap kegiatan manusia, maka pemecahan masalah lingkungan tidak hanya ditujukan pada akar penyebabnya krisis tetapi 
juga membantu menciptakan pemecahan yang sistemik yang dapat menanggulangi berbagai masalah lingkungan. Pemecahan pada tingkat akar permasalahan merupakan penerapan prinsip berkelanjutan yang ditujukan terhadap beberapa masalah lingkungan secara simultan. Di samping itu juga bahwa pemecahan pada tingkat akar permasalahan dapat mengurangi tenaga dan uang dibanding dengan pemecahan secara tradisional.

Tabel 1. Perbandingan pemecahan secara tradisional dengan pemecahan yang menerapkan prinsip berkelanjutan.

\begin{tabular}{|c|c|c|c|c|}
\hline Masalah & Pemecahan Tradisional & Komentar & Pemecahan Sustainable & Komentar \\
\hline $\begin{array}{l}\text { Pencemaran udara dari } \\
\text { pabrik berbahan bakar } \\
\text { batubara }\end{array}$ & $\begin{array}{l}\text { Pembuatan cerobong } \\
\text { asap }\end{array}$ & 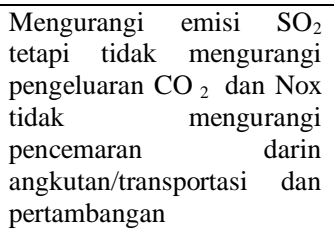 & $\begin{array}{l}\text { Efisiensi energi dan daur } \\
\text { ulang }\end{array}$ & $\begin{array}{l}\text { Mengurangi semua bentuk } \\
\text { pencemaran dari } \\
\text { pertambangan, } \\
\text { transportasi, dan } \\
\text { pembakarn batubara, } \\
\text { mengurangi habitat akibat } \\
\text { penggalian dan eksplorasi }\end{array}$ \\
\hline $\begin{array}{l}\text { Menngkatnya kebutuhan } \\
\text { air }\end{array}$ & $\begin{array}{l}\text { Membuat } \\
\text { baru }\end{array}$ & $\begin{array}{l}\text { Menghancurkan aliran } \\
\text { sungai; mengurangi habitat } \\
\text { organisme; mengurangi } \\
\text { sumber rekreasi alami, } \\
\text { memerukan energi dan } \\
\text { sumber lain untuk } \\
\text { membangun bendungan }\end{array}$ & & $\begin{array}{l}\text { Melindungi sungai dan } \\
\text { habitat liar; melindungi } \\
\text { sumber rekreasi, } \\
\text { menggunakan energi dan } \\
\text { sumber lain yang lebih } \\
\text { kecil }\end{array}$ \\
\hline $\begin{array}{l}\text { Meningkatnya kebutuhan } \\
\text { energi }\end{array}$ & $\begin{array}{l}\text { menambang batubara } \\
\text { lebih banyak lagi atau } \\
\text { mencari sumber minyak } \\
\text { dan gas }\end{array}$ & $\begin{array}{l}\text { Meningkatkan semua } \\
\text { bentuk pencemaran, } \\
\text { meningkatkan pengrusakan } \\
\text { habitat dan dapat } \\
\text { mengakibatkan kepunahan } \\
\text { spesies }\end{array}$ & $\begin{array}{l}\text { Menggunakan energi } \\
\text { secara lebih efisien, daur } \\
\text { ulang menggunakan } \\
\text { sumber-sumber yang } \\
\text { dapat diperbaharui; } \\
\text { pengendalian pertambahan } \\
\text { penduduk }\end{array}$ & $\begin{array}{lr}\text { Mengurangi semua bentuk } \\
\text { pencemaran, } & \text { mengurangi } \\
\text { pengrusakan } & \text { habitat, } \\
\text { mengurangi } & \text { kepunahan } \\
\text { spesies, } & \text { mengurangi } \\
\text { pemanasan } & \text { global, } \\
\text { mengurangi } & \text { penipisan } \\
\text { mineral } & \end{array}$ \\
\hline
\end{tabular}

Agar pembangunan dapat terlanjutkan, ada tiga syarat yang harus dipenuhi yaitu syarat ekonomi, sosial budaya dan ekologi. Persyaratan ekonomi telah diketahui sejak lama sekali, sedangkan syarat sosial budaya dan ekologi baru disadari setelah 30-40 tahun yang lalu setelah muncul permasalahan budaya memelihara hasil pembangunan dan masalah lingkungan.

\section{Peran Aktif Dalam Transformasi Lingkungan Berkelanjutan}

Para ahli biologi seperti halnya kelompok masyarakat lainnya memiliki tanggung jawab yang sama bahkan lebih besar untuk ikut berperan aktif di dalam menanggulangi masalah lingkungan. Banyak perubahan yang diperlukan untuk membangun masyarakat yang menerapkan prinsip berkelanjutan. Sustainable society perlu dibangun sesegera mungkin dan tak bisa ditawar lagi agar kehidupan dapat berlangsung terus. Membangun sustainable society bukan hanya harus dimulai dari setiap individu tetapi juga memerlukan perubahan dalam kebijakan pemerintah dan tindakan hukum serta badan hukum dan terlebih penting adalah perubahan dalam gaya hidup.

Para ahli biologi dapat memulai mempresentasikan prinsip berkelanjutan dan mendorongnya melalui diskusi yang aktif di dalam ataupun di luar kelas. Para ahli biologi harus menjadi pelopor di dalam mendorong anggota masyarakat lainnya untuk mengimplementasikan prinsip berkelanjutan. Tentu di dalam proses tersebut, biologi akan menjadi lebih dari suatu bidang studi yang tidak hanya bersifat hafalan tetapi harus berkaitan langsung dengan dunia nyata. Sebenarnya para ahli biologi dapat mengambil peran aktif di dalam transformasi prinsip berkelanjutan, melalui berbagai cara, diantaranya:

1. Mempengaruhi perilaku orang lain di sekeliling kita.

2. Mendorong perubahan kebijakan publik melalui surat, lobby, kerjasama dan usaha lainnya.

3. Menjadi warga negara yang lebih baik dengan berpikir dan bertindak berdasarkan prinsip lingkungan berkelanjutan

Masyarakat berdasarkan prinsip berkelanjutan adalah masyarakat yang sangat alami, holistik dan selalu mengantisipasi (Chiras, 1992). Sustainable society, keputusannya menekankan kepada biosfer secara keseluruhan (as a whole), mengantisipasi semua dampak menembus ruang dan waktu. Sustainable society selalu mencari usaha untuk melestarikan ekosistem agar selalu berfungsi dengan baik, dan memahami benar bahwa tidak akan ada pertumbuhan ekonomi yang sehat tanpa ekosistem yang sehat. Jadi sustainable society harus memprioritaskan kegiatannya, bidang usahanya, pemerintahannya, gaya hidupnya kepada hal yang lebih penting bukan kepada keuntungan jangka pendek 
dan pemenuhan kebutuhan manusia sesaat tetapi ditujukan kepada "rumah kita, planet bumi yang baik secara ekologis. Transisi menjadi sustainable society bagaimanapun juga memerlukan bukan hanya cara baru bertindak, tetapi harus memikirkan kembali tentang planet kita ini. Dengan kata lain memerlukan satu pandangan dunia baru dalam kaitannya dengan prinsip-prinsip biologi tentang lingkungan berkelanjutan.

\section{KESIMPULAN}

Konsep pembangunan berkelanjutan berhubungan erat dengan masalah etika, mengingat bahwa konsep pembangunan berkelanjutan berorientasi pada masa depan (future) dan juga memfokuskan diri pada masalah kemiskinan (poverty). Konsep ini sangat memperhatikan kesejahteraan generasi yang akan datang, namun pada saat yang bersamaan juga tidak mengurangi perhatian terhadap upaya-upaya untuk meningkatkan taraf hidup orang-orang miskin yang ada pada generasi sekarang. Tujuan pembangunan berkelanjutan yang bermutu adalah tercapainya standar kesejahteraan hidup manusia dunia akhirat yang layak, cukup sandang, pangan, papan, pendidikan bagi anak-anaknya, kesehatan yang baik, lapangan kerja yang diperlukan, keamanan dan kebebasan berpolitik, kebebasan dari ketakutan dan tindak kekerasan, dan kebebasan untuk menggunakan hak-haknya sebagai warga Negara. Bila prinsip berkelanjutan diterapkan terhadap kegiatan manusia, maka pemecahan masalah lingkungan tidak hanya ditujukan pada akar penyebabnya krisis tetapi juga membantu menciptakan pemecahan yang sistemik yang dapat menanggulangi berbagai masalah lingkungan.

\section{DAFTAR PUSTAKA}

Chiras, D.D. (1991). Environmental Science: Action for a sustainable future. Redwood city CA: Benjamin Cummings (1992). Lessons from Nature: Learning in to live sustainably on the Earth. Washington: Island Press. (1993). Eco-Logic: Teaching the Biological Principles of Sustainability, The American Biology Teacher, 55 (2): 71-76.

Prihantoro, L. (1989). Manusia dan Lingkungan Hidup. Bandung: FPMIPA-IKIP

Salim, E. (1979). Lingkungan Hidup dan Pembangunan. Jakarta: Mutiara

Soemarwoto, O. (1987). Ekologi, Lingkungan Hidup dan Pembangunan. Jakarta: Djambatan (1992). Indonesia Dalam Kancah Isu Lingkungan Global. Jakarta: Gramedia

Swan, J. A. and Stapp, W.B. (1974). Environmental Education: strategies Toward a More Livable Future. New York: John Willey \& Sons.

Zen, M.T. (1979). Menuju Kelestarian Lingkungan Hidup, Jakarta: Gramedia 